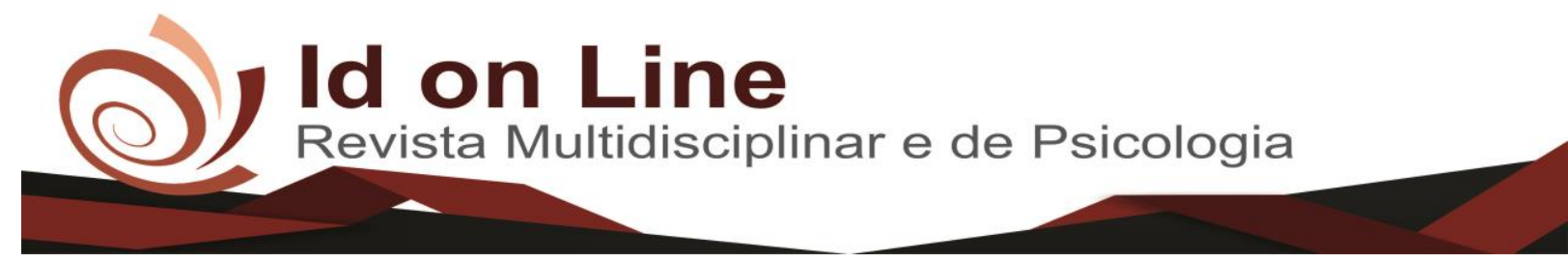

Artigo

\title{
A Medida Liminar em Habeas Corpus
}

\author{
Barbara Maria Moreira Dante Santaguida ${ }^{1}$; Gisanne de Oliveira Marinho ${ }^{2}$ \\ Juliana de Fátima dos Santos Santiago ${ }^{3}$; Athena de Albuquerque Farias ${ }^{4}$
}

\begin{abstract}
Resumo: O objetivo do presente estudo foi analisar a concessão do uso de liminar em habeas corpus. Buscou-se introduzir inicialmente, o conceito do instituto através da doutrina e da própria legislação constitucional, à construção histórica e desenvolvimento do instituto para chegar à natureza jurídica do habeas corpus. Discute-se ainda o direito tutelado pelo remédio judicial, ou seja, a liberdade e suas características peculiares ao direito de ir, vir, permanecer e circular. A discussão avança para as condições da ação do habeas corpus, tratando finalmente das tutelas provisórias e da procedência de liminar em habeas corpus. Trata-se de um estudo descritivo, histórico e documental. Os resultados levam a crer ser necessária a concessão de liminar em habeas corpus, quando da urgência da medida definitiva e, a demora nos julgamentos. Quando se busca a tutela da liberdade do cidadão, é inadmissível a morosidade jurisdicional.
\end{abstract}

Palavras-chave: Habeas corpus. Direito. Medida liminar.

\section{The Preliminary Injunction in Habeas Corpus}

\begin{abstract}
The aim of the article is to analyze the concession of the use of the preliminary injunction in habeas corpus. Initially, introducing the concept of the institute through the doctrine and the constitutional legislation itself, to the historical construction and development of the institute to reach the legal nature of habeas corpus. It also discusses the right protected by the judicial remedy, that is, freedom and its characteristics peculiar to the right to come and go, stay and move. The discussion advances to the conditions of habeas corpus action, finally dealing with provisional tutelages and the origin of the preliminary injunction in habeas corpus. This is a descriptive, historical and documentary study. The results suggests that it is necessary to grant an preliminary injunction in habeas corpus, when the final measure is urgent, and there is delay in judgments. When seeking the protection of the freedom of the citizen, is inadmissible the jurisdictional slowness.
\end{abstract}

Keywords: Habeas corpus. Right. Preliminary injunction.

\footnotetext{
${ }^{1}$ Concluinte de Direito pela Universidade Regional do cariri - URCA. Contato: barbara.santaguida@ gmail.com;

${ }^{2}$ Advogada pela Universidade Federal Fluminense. Mestranda em Justiça Administrativa na Universidade Federal Fluminense. Avaliadora e revisora da Id On Line Revista Multidisciplinar e de Psicologia (ISSN 1981-1179). Associada da Ordem dos Advogados do Brasil, Seccional do Rio de Janeiro. Contato: gimarinho@gmail.com;

${ }^{3}$ Advogada pela Universidade de Caxias do Sul - UCS, Paraná. Contato: Jfssantiago1@ gmail.com;

${ }^{4}$ Advogada formada pela Faculdade dos Guararapes - Recife - Pernambuco. Especialista em Direito Processual do Trabalho pela Faculdades Integradas de Cruzeiro - SP. Editora Adjunta do Periódico Científico Id on Line Revista Mutidisciplinar e de Psicologia. Contato: athena.farias@gmail.com.
} 


\section{Introdução}

Desde os tempos antigos, o homem sofre com constrangimentos a sua liberdade de circulação ou ameaça à essa liberdade. O fenômeno ocorre naturalmente uma vez que vivemos em sociedade, compartilhando o mesmo espaço e meio com outros seres humanos. No entanto, não raro que o constrangimento à liberdade de locomoção venha acompanhado de ilegalidade e violência.

Apresentada a problemática do cerceamento à liberdade, busca-se uma solução. A mesma sociedade, cuja vida comunitária pode levar à tal sujeição, encontra no reconhecimento e afirmação dos direitos fundamentais, uma resposta através da ordem jurídica. O habeas corpus entra em cena como figura garantidora do direito à liberdade.

Apesar da similitude com instrumento utilizado no direito romano, a doutrina admite ter sido o habeas corpus criado durante o século XIII pelo direito inglês, seja nos ditames da common law como expressamente no Habeas Corpus Act. A limitação dos poderes centralizados no rei e a reinvindicação de mais direito outorgados aos nobres e homens-livres deu gênese ao pensamento contrário às detenções injustificadas. Que tenhas o corpo é, literalmente, o significado de habeas corpus, e a partir daí, se aprecie pelo magistrado a legalidade da restrição de liberdade imposta.

Com a evolução do tempo, a sociedade muda sua forma de agir e pensar, e assim segue o direito. Ao estudarmos o habeas corpus, percebe-se que a passagem temporal fortaleceu o instituto. No período iluminista-humanista, e no cenário pós Segunda Guerra, os direitos fundamentais ganharam papel de destaque. A liberdade é direito fundamental inerente ao homem, e o guardião da garantia de liberdade de locomoção contra atos ilegais na restrição da mesma é o habeas corpus. A consagração dos direitos fundamentais trouxe consigo a exponencial popularização na quantidade de pedidos de habeas corpus.

Segundo dados do CNJ, Conselho Nacional de Justiça, até a presente data, maio de 2018, tramitam entre as cortes do STF e do Superior Tribunal de Justiça aproximadamente 38.000 (trinta e oito mil) ações de habeas corpus. O número já volumoso de processos cresce a cada ano, engessando a função jurisdicional do Estado, que deveria apresentar respostas às demandas de maneira eficaz. Esta carência de celeridade e efetividade na resolução de litígios abre espaço para o questionamento atinente ao tema do estudo. É de fato necessário utilizar-se de medidas 
provisórias não definitivas de mérito em um procedimento que em tese deveria ser simplificado e célere?

O objetivo deste estudo foi analisar e demonstrar a necessidade do uso de liminar em habeas corpus. Busca-se introduzir inicialmente, o conceito do instituto através da doutrina, da própria legislação constitucional e até mesmo de análise etimológica. Remonta-se à construção histórica e desenvolvimento do instituto para chegar à natureza jurídica do habeas corpus. Discute-se ainda o direito tutelado pelo remédio judicial, ou seja, a liberdade e suas características peculiares ao direito de ir, vir, permanecer e circular. A discussão avança para as condições da ação do habeas corpus, tratando finalmente das tutelas provisórias e da procedência de liminar em habeas corpus.

\section{Metodologia}

A metodologia é indutiva, de procedimento documental e histórico, com o intuito de compreender de maneira mais ampla, o tema abordado. Também utilizar-se-á o método comparativo, por meio do qual se realizará comparações entre o presente e o passado. O estudo será realizado através de pesquisa bibliográfica, embasada em doutrinas, em artigos científicos, jurisprudência, no Código Civil de Processo Penal de 1941 e na Constituição Federal de 1988.

\section{Conceito de Habeas Corpus}

O instituto estudado destina-se a impor limites a qualquer ilegalidade ou abuso de poder que se relacione a liberdade de ir, vir, e permanecer, tanto penalmente quanto no âmbito civil. Tal ação constitucional é prevista como cláusula pétrea no art. $5^{\circ}$, LXVIII, da Constituição Federal e regulada no Capítulo X do Título II do Livro III do Código de Processo Penal, portanto da Constituição Federal temos que:

Art. $5^{\circ}$ Todos são iguais perante a lei, sem distinção de qualquer natureza, garantindose aos brasileiros e aos estrangeiros residentes no País a inviolabilidade do direito à vida, à liberdade, à igualdade, à segurança e à propriedade, nos termos seguintes: 
LXVIII - conceder-se-á habeas corpus sempre que alguém sofrer ou se achar ameaçado de sofrer violência ou coação em sua liberdade de locomoção, por ilegalidade ou abuso de poder; (BRASIL. Constituição Federal,1988).

Adiante, no mesmo artigo citado, a Constituição Federal garante sua gratuidade:

LXXVII - são gratuitas as ações de habeas corpus e habeas data, e, na forma da lei, os atos necessários ao exercício da cidadania.

Consequentemente extraímos do Código de Processo Penal:

Art. 647. Dar-se-á habeas corpus sempre que alguém sofrer ou se achar na iminência de sofrer violência ou coação ilegal na sua liberdade de ir e vir, salvo nos casos de punição disciplinar. (BRASIL. Código de Processo Penal, 1941).

Não há no ordenamento jurídico pátrio legislação que alcance a importância da Constituição. Na Carta Magna o habeas corpus, como demonstrado, é elencado no rol dos direitos fundamentais e individuais, característica de constituições democráticas e ponto inicial da ordem jurídica. Os direitos individuais são salvaguardados também na constituição como cláusula pétrea, não susceptível a mutações. No código de processo penal, é o habeas corpus compreendido como um remédio judicial e recurso.

De maneira ampla, é uma ação popular, passível de ajuizamento por qualquer representante do povo que, em seu favor ou de outrem, tenha sua liberdade de locomoção constrita ou ameaçada. Iniciando o discurso com o que dizia Oliveira Machado, ainda no século XIX:

Nenhum remédio é mais salutar, mais poderoso a garantir a liberdade suprimida ou cerceada que o habeas corpus, cujo fim é aliviar o paciente com verdadeira presteza e admirável prontidão, da opressão ilegal. O habeas corpus é o salvo-conduto eficaz, a carta de crédito vigilante e defensora que preserva a liberdade contra os ataques iníquos e injuriosos. (MACHADO, Joaquim de Oliveira, 1878, p.10)

Pacheco (José Ernani de Carvalho. Habeas Corpus: prática, processo e jurisprudência. p. 22), conceitua Habeas Corpus como "A ação constitucionalmente garantida a todo indivíduo, nacional ou estrangeiro, apta a impedir ou cessar uma prisão ou constrangimento ilegal em sua liberdade física, decorrente de ilegalidade ou abuso de poder".Complementa Tourinho Filho (2014, p.669): que o instituto é um remedium juris, cuja finalidade é tutelar de maneira imediata a liberdade de locomoção. 
Etimologicamente, o termo habeas corpus, vem do latim (habeo, habere $=$ ter, exibir, tomar, trazer; corpus = corpo), quer dizer "toma o corpo", portanto, que se faça presente aquele que esteja preso, em juízo, para que a ordem que restrinja sua liberdade seja justificada e para que caiba ao juiz decidir manter tal ordem ou revoga-la. Nas palavras de Pontes de Miranda:

Toma o corpo deste detido e vem submeter ao Tribunal o homem e o caso. "Por onde se vê que era preciso produzir e apresentar à Corte o homem e o negócio, para que pudesse a Justiça, convenientemente instruída, estatuir, com justiça, sobre a questão e velar sobre o indivíduo". (PONTES DE MIRANDA, 1961, p.21).

O conceito do habeas corpus, refere-se a uma garantia constitucional, que toma forma como ação constitucional popular, com a finalidade de tutelar o direito à liberdade de locomoção de maneira rápida e imediata, podendo ser requerida por qualquer cidadão em solo pátrio, mesmo que estrangeiros, se assim necessitarem do seu amparo em caso de violação ou ameaça de violação do direito à liberdade de ir, vir ou permanecer. O habeas corpus é o remédio constitucional que tutela o direito individual fundamental da liberdade.

A liberdade objetiva, é gênero da liberdade de locomoção. A Constituição Federal assegura em seu artigo $5^{\circ}$ a inviolabilidade do direito à liberdade, essa segurança é garantida objetivamente pelo remédio constitucional em estudo. É realizado um recorte jurídicofilosófico no que toca a este direito fundamental.

Tendo como base a doutrina e o ordenamento jurídico nacional, mergulhamos, em sequência, em uma breve apresentação da evolução histórica do instituto, de seu início, no período romano até os dias atuais e de seu espaço histórico no Brasil, como maneira de situar o remédio constitucional, demonstrando sua notoriedade através do tempo nas leis estrangeiras e brasileira.

Uma ação constitucional de impugnação, com o intuito de coibir qualquer coação ou violação no tocante à liberdade de locomoção, assim admitimos a natureza jurídica do habeas corpus. De procedimento não só eficaz como também eficiente pela sua notável celeridade no papel de garantir a liberdade, sua ação alcança direitos fundamentais vizinhos a sua tutela, como a intimidade, a vida privada, a integridade física, a dignidade da pessoa humana e enfim, a vida. Não à toa é denominado popularmente como remédio heroico. 


\section{Liberdade: Construção Histórica e Jurídica}

Das diversas assumpções que o termo liberdade - do latim libertas, atis -podemos assumir que, focamo-nos na liberdade de pessoa física, que é voltada à liberdade de locomoção e circulação, indicando genericamente a condição de livre ou estado de liberdade.

Concernente ao conceito jurídico significa a faculdade ou o poder outorgado à pessoa para que possa agir segundo sua própria determinação, seguindo a autonomia da sua vontade e respeitando as regras legais instituídas. É difícil se alcançar um conceito uno e fechado de liberdade, visto que o mesmo sofreu diversas mudanças com a evolução dos tempos, até chegar à ideia que abraçamos na contemporaneidade, para isso, devemos fazer uma curta digressão ao passado.

Para o filósofo inglês John Locke, seria impossível atingir a liberdade sem o auxílio das leis, deixando sua marca quando citamos que "Onde não há lei, não há liberdade". Montesquieu aprofunda em sua obra $O$ Espírito das Leis, a busca por um significado para a palavra liberdade e chega a este num sentido político, quando infere que a liberdade política consiste em fazer aquilo que as leis permitem, e não o que desejam as pessoas deliberadamente, tampouco ser constrangido a fazer o que não se deve querer. Os limites da liberdade são deste modo, estabelecidos pela lei.

Trazendo o conceito para o estudo em questão, nos interessa saber que a liberdade é um direito civil, e sendo parte dos direitos individuais do homem, o Estado tem a obrigação de assegurar para que a vida dos cidadãos tenha o mínimo de dignidade. A Constituição Federal de 1988, no artigo $3^{\circ}$, a elenca como um de seus fundamentos básico a construção e manutenção de uma sociedade livre, justa e solidária: "Art. 3: Constituem objetivos fundamentais da República Federativa do Brasil: I - construir uma sociedade livre, justa e solidária;”.

Também figura nos direitos e garantias fundamentais do mesmo ordenamento, mais especificamente no caput do artigo $5^{\circ}$ da nossa Magna Carta:

Art. $5^{\circ}$ Todos são iguais perante a lei, sem distinção de qualquer natureza, garantindose aos brasileiros e aos estrangeiros residentes no País a inviolabilidade do direito à vida, à liberdade, à igualdade, à segurança e à propriedade, nos termos seguintes.

Neste ponto nos detemos a discutir a liberdade da pessoa física, em sua forma de liberdade de locomoção, um direito fundamental reconhecido no inciso XV do artigo $5^{\circ}$ da 
Constituição Federal nos seguintes termos: "É livre a locomoção no território nacional em tempo de paz, podendo qualquer pessoa, nos termos da lei, entrar, permanecer ou dele sair com seus bens".

O direito a liberdade de locomoção, mencionado pela Constituição e objeto de tutela do habeas corpus, consiste em poder a pessoa escolher permanecer ou residir no lugar que deseje, de circular livremente, ir de um lugar para outro, viajar, entrar ou sair do território nacional (do direito romano: jus manendi, ambulandi, eundi, ultro citroque). Se o ir e vir ocorre pelo deslocamento na via pública, fala-se em liberdade de circulação; se ocorre, no entanto, através das fronteiras nacionais, fala-se em liberdade de emigração e imigração.

Direito fundamental do homem como pessoa física independente de nacionalidade ou residência no país, é exercido por terra, mar e ar, com ou sem a utilização de veículos. É suscetível a regulamentação, pois como ensina Alexandre Moraes, trata-se de norma constitucional abstrata, de eficácia contida, na qual a lei ordinária irá delimitar a amplitude e pressupostos de forma e fundamentação, nunca sendo oriunda de previsões arbitrárias. Portanto, o legislador ordinário pode estabelecer restrições à entrada, saída e circulação de pessoas. (MORAES, 2015).

O direito de entrar e sair do território nacional em tempo de paz pode ser condicionado, ao "visto de entrada" quando concerne a estrangeiros. Em período de guerra externa deflagrada, salvo para o brasileiro que queira regressar à pátria, subordina-se ao poder discricionário das autoridades, informado pelo interesse da segurança do país. As restrições à liberdade só podem existir por um período de tempo definido e quando há previsão legal, como a detenção em flagrante, a aplicação da pena de prisão, a prisão preventiva, quando se sujeita um menor à medidas de proteção ou assistência em adequado estabelecimento, dentre outras situações.

Direito público subjetivo, o direito de locomoção constitucionalmente consagrado não faz uso do habeas corpus para trancar a ação penal, sem justa causa, a ela movida. Para esse fim, é adequado o mandado de segurança. A recepção dos direitos individuais no ordenamento jurídico pressupõe o percurso de longa trajetória, que afirma a precedência dos direitos individuais inatos, naturais, imprescritíveis e inalienáveis do homem. A liberdade é um princípio fundamental para o crescimento e desenvolvimento de qualquer sociedade, sem ela, causam-se danos irreparáveis em uma sociedade, e compromete-se até mesmo o exercício do direito à vida. 


\section{Origem do Habeas Corpus no Direito Brasileiro}

No Brasil, a constituição de 1824 não mencionava expressamente o habeas corpus, porém, certos direitos e garantias já eram instituídos com a finalidade de tutelar o direito à liberdade. O Código de Processo Penal, de 1832, trouxe expressamente o habeas corpus, de modo que a partir daí houvera a introdução do instituto no ordenamento jurídico pátrio.

A proteção do direito à liberdade foi alargada com a Lei 2.033, de 1871, que instituiu o Habeas Corpus preventivo sendo, portanto, forma de evitar a agressão ao direito de locomoção do cidadão, além de estender seu alcance também a estrangeiros. A constituição de 1891 elevou-o à categoria de garantia constitucional, mas como não fazia a redação da norma alusão direta ao direito de liberdade de locomoção, a proteção que resguardava era contra "iminente perigo de sofrer violência ou coação por ilegalidade ou abuso de poder".

A partir daí iniciou-se um confronto entre os doutrinadores e juristas da época. De um lado havia aqueles que defendiam o habeas corpus como remédio garantidor apenas da constrição de liberdade locomotiva, por outro lado havia os que, valendo-se da amplitude da norma, justificavam seu uso sem quaisquer restrições, não garantindo apenas a liberdade locomotiva, mas também garantindo outras liberdades individuais. A primeira posição era amparada por Pedro Lessa, enquanto que esta última era defendida por Rui Barbosa e apoiada pelo Supremo Tribunal Federal.

Em 1926, após décadas, com a reforma constitucional foi restabelecido o conceito histórica do instituto, diminuindo-se a amplitude de atuação do writ, relacionando-o diretamente à liberdade locomotiva, dispondo no seu artigo 113, inciso XXIII: "Dar-seá Habeas Corpus sempre que alguém sofrer, ou se achar ameaçado de sofrer violência ou coação em sua liberdade, por ilegalidade ou abuso de poder. Nas transgressões, disciplinares não cabe o habeas corpus.”.

Para amparar outros direitos, foi criado o mandado de segurança, dispondo a Lei Maior dessa forma no artigo 133, inciso XXXIII, afirmando que, "Dar-se-á mandado de segurança para a defesa do direito, certo e incontestável, ameaçado ou violado por ato manifestamente inconstitucional ou ilegal de qualquer autoridade. O processo será o mesmo do Habeas corpus, devendo ser sempre ouvida à pessoa de direito público interessada.”. 
Com o passar do tempo, poucas foram as constituições que abrangiam o caráter mais elástico do remédio judicial. As constituições subsequentes de 1946, 1967 e 1988 mantiveram em seus textos o habeas corpus, decretando o ordenamento constitucional vigente, no inciso LXVIII do artigo 5': "Conceder-se-á Habeas Corpus sempre que alguém sofrer ou se achar ameaçado de sofrer violência ou coação em sua liberdade de locomoção, por ilegalidade ou abuso de poder".

Afinado à Constituição Federal de 1988, dispõe o atual Código de Processo Penal, no seu artigo 647: "Dar-se-á Habeas Corpus sempre que alguém sofrer ou se achar na iminência de sofrer violência ou coação ilegal na sua liberdade de ir e vir, salvo nos casos de punição disciplinar.".

Vale destacar que, durante a ditadura militar o habeas corpus foi sempre ameaçado. Toma-se como maior exemplo disso o AI - 5 (Ato Institucional n. 5), de 13 de dezembro de 1968, que em seu artigo 10, afirmava que, "fica suspensa a garantia de habeas corpus nos casos de crimes políticos, contra a segurança nacional, a ordem econômica e a economia popular". Apesar dos arrochos sofridos no tocante aos direitos fundamentais individuais, por contraditório que seja a primeira liminar em habeas corpus aconteceu em 1964, em um tribunal militar. Em 1969 fora promulgada a emenda número I, de 17/10/1969, repetindo o regramento dado pela Constituição de 1967, que era até então mantido o mesmo da Constituição de 1946. Mesmo com a redação da emenda constitucional, o AI - 5 foi mantido, sendo revogado somente no ano de 1978.

Ressalta-se ainda que a Constituição Federal vigente, de 1988, no seu regramento supracitado, suprime a expressão primeiramente utilizada pela Constituição de 1946, "nas transgressões disciplinares não caberá habeas corpus", portando-nos a uma conclusão que não importa o tipo de ameaça ou lesão, desde que se relacionem ao direito de ir, vir, e permanecer, sempre caberá a atuação do writ.

\section{Natureza Jurídica do Habeas Corpus}

Do Código de Processo Penal, no livro III título II, capítulo I, artigo 574, nos deparamos com tal disposição: "Os recursos serão voluntários, excetuando-se os seguintes casos, em que deverão ser interpostos, de ofício, pelo juiz: I - da sentença que conceder habeas corpus”. 
Ao contrário do que leva a crer a lei processual penal, não se trata de recurso, e sim de ação autônoma que atinge uma relevante garantia humana fundamental. Dentre algumas das razões pelas quais não é recurso, pode-se ressaltar a inexistência de prazo para sua propositura, bem como seu poder de ser impetrada contra ato de autoridade coatora. No caso dos recursos, são cabíveis apenas contra decisão judicial e não contra particular.

Outra razão para não considerarmos o habeas corpus recurso é pelo fato do mesmo instaurar uma nova relação jurídica, independentemente de qualquer outra, diferentemente do recurso, que pressupõe uma relação jurídica já existente. Seu caráter sui generis, no entanto a permite atuar como recurso, afim de reparar em instância superior, erros cometidos em instância inferior do Judiciário.

Muitos foram os doutrinadores que se preocuparam com a natureza jurídica do instituto, alguns adotando-o como puramente um recurso processual, outros como ação. Rui Barbosa (1928, p.57) classificou o habeas corpus como garantia constitucional, distinguindo garantias e direitos constitucionais:

\begin{abstract}
Uma coisa são garantias constitucionais, outra coisa os direitos, de que estas garantias traduzem, em parte, a condição de segurança política ou judicial. Os direitos são aspectos, manifestações da personalidade humana em sua existência subjetiva, ou nas situações de relação com a sociedade, ou os indivíduos que a compõe. As garantias constitucionais, 'stricto sensu', são as solenidades tutelares, de que a lei circunda alguns desses direitos contra os abusos de poder.
\end{abstract}

Compreende-se do pensamento de Rui Barbosa que os direitos fundamentais são de natureza meramente declaratórias, expondo a existência normativa; já as garantias fundamentais são de ordem assecuratória, isto é, asseguram à pessoa as limitações do poder estatal. Sobre este mesmo assunto, refletiu Jorge Miranda (2012, t.4, p.95):

\begin{abstract}
As liberdades são formas de manifestação das pessoas; as garantias pressupõem modos de estruturação do Estado, as liberdades envolvem sempre a escolha entre o 'facere' e o 'non facere' ou entre agir e não agir em relação aos correspondestes bens, têm sempre uma dupla face - positiva e negativa; as garantias têm sempre um conteúdo positivo, de atuação do Estado ou das próprias pessoas. As liberdades valem por si; as garantias têm função instrumental derivada.
\end{abstract}

O direito de ir e vir é manifestado diversas vezes na Constituição Federal, e a mesma consagrou a garantia do habeas corpus como uma segurança, uma prestação jurisdicional não apenas reparadora, mas também de caráter cautelar. A garantia prestada pelo habeas corpus está inscrito nas chamadas garantias constitucionais especiais, quais sejam aquelas que 
determinam mecanismos e técnicas onde a atuação de órgãos ou particulares seja limitada para proteger a inviolabilidade, eficácia e aplicação dos direitos fundamentais, desta maneira não são um fim em si mesmas, mas instrumentos que tutelam um direito principal.

Pelo seu caráter instrumental, o habeas corpus requer regras que se adequem ao seu processamento. Explica Rogério Tucci (1978, p.5) que: "Embora instituto de direito constitucional, o habeas corpus assegura, praticamente, a liberdade de locomoção somente depois do ato jurisdicional, que o concede, sendo que tal prestação só pode resultar da ação judiciária.".

A noção do habeas corpus como recurso foi relevante no período do Brasil Império, mas já na República Velha não era utilizada. O recurso é um meio de conseguir reformar uma decisão não favorável de autoridade, o habeas corpus não implica decisão anterior a ser reformada e pode ser impetrado contra particular. Quando contesta decisão de autoridade, o mesmo não está sujeito a prazo de interposição e a função recursal que carrega não transforma sua natureza de ação autônoma em recurso.

A ação é um direito subjetivo, autônomo, público e abstrato que se conecta a uma relação jurídica de direito material através da manifestação em juízo de uma determinada pretensão. Entretanto, não só através da ação se efetiva a garantia constitucional do habeas corpus.

Também é possível atingir tal garantia pelo exercício da jurisdição não provocada por demanda do autor e independentemente da instauração de processo de partes.

O direito brasileiro contempla o habeas corpus de ofício, que não se encaixa ao conceito de ação judicial nem menos de recurso. Este fenômeno de exceção no processo penal foi denominado por Carnelutti como "jurisdição sem ação”. Há na doutrina divergências sobre a atuação do juiz em tais situações, porém não restam dúvidas que no direito brasileiro são admitidos a ação de habeas corpus e o exercício espontâneo da jurisdição pelo habeas corpus de ofício para a efetivação da garantia do habeas corpus.

É o que extraímos da Súmula 93 das Mesas de Processo Penal da Faculdade de Direito da Universidade de São Paulo: “O habeas corpus é garantia processual penal do direito de locomoção, e no plano processual tem a natureza jurídica de ação, se impetrado por terceiro ou pelo paciente; quando concedido de ofício, representa a manifestação do exercício espontâneo da jurisdição.”. Tal entendimento é abraçado pela doutrina e difundido na jurisprudência nos casos em que se deve ser aplicado. 


\section{Da Possibilidade Jurídica do Pedido}

A ação do habeas corpus é cabida quando a sua finalidade é resgatar à liberdade individual, que por qualquer constrangimento, esteja restrita ou ameaçada de restrição. Tal fundamento jurídico, disposto no artigo $5^{\circ}$, inciso LXVIII da CF/88 diz que: "concede-se habeas corpus quando alguém sofrer ou se achar ameaçado de sofrer violência ou coação em sua liberdade de locomoção, por ilegalidade ou abuso de poder.".

Como condição inicial da ação, deve-se verificar a possibilidade jurídica do pedido, ou seja, se a liberdade individual está em risco. Na teoria, em não se tratando de liberdade de locomoção, não seria juridicamente viável ajuizar o habeas corpus. Havendo a constrição de algum outro direito fundamental, mais apropriado é fazer uso do mandado de segurança, exposto no artigo $5^{\circ}$, LXIX: “concede-se mandado de segurança quando algum direito líquido e certo for violado por ato abusivo ou ilegal de autoridade.".

Ao tratar-se da possibilidade do pedido pleiteado pelo habeas corpus, notável é o fato que a viabilização do uso da ação de habeas corpus alastrou-se de maneira que atinge searas vizinhas ao direito de locomoção, desde que este seja, de alguma forma, atingido, mesmo que indiretamente. Com tal característica que acomete o ajuizamento da ação, é praticamente impossível, no direito brasileiro, delimitar precisamente, a possibilidade jurídica do pedido.

Em um contexto abrangente da possibilidade jurídica do pedido, é complexo e trabalhoso a sua avaliação, circunstância pela qual o mais indicado é permitir o processamento da demanda, cujo rito é célere e abreviado, proferindo, caso seja necessário, decisão de mérito indeferindo a ordem.

Ada Pellegrini (1987) nos ensina que, é uma tendência corrente, atrelado aos movimentos para o acesso à justiça, a redução dos casos de impossibilidade jurídica do pedido, também chamada de tendência à universalização da jurisdição, em que a jurisprudência busca ampliar a extensão do que considera os aspectos da legalidade dos atos, como consequência do que fora examinado pelos tribunais.

Destarte, a análise das condições da ação de habeas corpus deve ser feita de forma mais flexível do que uma ação distinta. A dúvida deverá sempre favorecer o impetrante e o paciente, nunca o próprio Estado. 
No direito processual penal, o exemplo de impossibilidade jurídica do pedido é, na doutrina majoritária, a ausência de tipicidade. Ao se tratar de ação de habeas corpus configura impossibilidade jurídica do pedido, a discussão acerca do mérito da ação penal, em que o paciente figura como réu. A ação mandamental não é o locus de análise para divagar sobre ser o acusado inocente ou culpado. Usando exemplo jurisprudencial sobre análise do mérito em sede de habeas corpus temos que:

O habeas corpus, conforme reiterada jurisprudência desta Corte Superior de Justiça, presta-se a sanar coação ou ameaça ao direito de locomoção, possuindo âmbito de cognição restrito às hipóteses de ilegalidade evidente, em que não se faz necessária a análise de provas. (HC 24021/SP, 6 T., rel. Maria Thereza de Assis Moura, 16.08.2012, v.u.).

Ressalta-se ainda que, como também ocorre no mandado de segurança, exige-se a evidência de direito líquido e certo. Pontes de Miranda, ao tratar do assunto diz que: "Direito líquido e certo é aquele que não desperta dúvidas, que está isento de obscuridades." Líquido é o que prescinde de apuração, pois já confirmado, em gênero, número e qualidade. É líquido porque, não restando dúvida sobre o pedido, o impetrante sabe com clareza o que pretende em favor do paciente. É certo pois resta incontestável e incontroverso, demonstrado com as provas documentais ofertadas com a inicial.

\section{A Liminar em Habeas Corpus}

O novo código de processo civil, vigente no ordenamento jurídico pátrio desde 2016, renovou ao apresentar conceitos amplos acerca das tutelas provisórias, trazendo, inclusive em seu corpo, mais detalhadamente no Livro $\mathrm{V}$ do código as especificações para cada gênero e espécie.

$\mathrm{Na}$ versão final do código não resta expresso a distinção entre tutelas urgentes cautelares (“assecuratórias") e antecipadas ("satisfatórias"). Pontes de Miranda dizia que: "a tutela cautelar garante para satisfazer, já a tutela antecipada satisfaz para garantir" Havendo qualquer imbróglio o juiz poderá, pela fungibilidade das subespécies, expressa no artigo 305 do NCPC, converter cautelar em antecipada, assim como o contrário, satisfazendo o que for mais adequado. 
As tutelas provisórias são caracteristicamente sumárias e não definitivas. Primeiramente sumárias porque não fazem um exame detalhado do que é pedido, sendo este menos aprofundado. Em razão disso, é natural que sejam não definitivas, apesar da inovação trazida no novo código com a possibilidade de estabilização da tutela antecipada; e apesar de muitas vezes, após o exame final do mérito haver sintonia entre a prolação da decisão final e a tutela provisória. A marca característica deste tipo de instrumento processual é a urgência com que demandam proteger a pretensão da parte litigante, até que seja pacificada a lide. Na urgência do pleito cabem as liminares.

A tutela provisória é mecanismo processual do tipo gênero, contando com as espécies de urgência e evidência. Na primeira conta-se com o elemento periculum in mora e com o fumus boni juris, não sendo estes exigidos na tutela de evidência.

Todos os instrumentos discutidos em questão encontram-se alicerçados no Direito Processual Civil, no entanto, o mesmo ordenamento tem aplicabilidade no Processo Penal. Nessa perspectiva, demonstra o artigo $3^{\circ}$, Decreto-Lei $n^{\circ} 3.689$, de 3 de outubro de 1941: “A lei processual penal admitirá interpretação extensiva e aplicação analógica, bem como o suplemento dos princípios gerais de direito." Fundamentando-se, portanto, a proposta de uso de tutelas provisórias como a liminar em sede de habeas corpus.

\section{Pressupostos para a Tutela de Urgência}

Como já citado, a tutela provisória de urgência pode dividir-se tanto em cautelares como também em antecipadas. O objetivo final do processo é o correto exercício da jurisdição, da qual faz parte a tutela de urgência. A tutela cautelar visa assegurar imediatamente a eficácia do próprio processo, protegendo o direito substancial apenas indiretamente, o que leva a um provimento sempre provisório.

Seguindo o raciocínio ensinado por José Alberto dos Reis (2004, p.1503) aprendemos que a medida cautelar não é um fim, é um meio e não se propõe a satisfazer imediatamente o direito material, mas tomar medidas que assegurem a eficácia da atuação do mesmo.

Os pressupostos fundamentais para que se realizem tal espécie de tutela provisória de urgência, sejam elas antecipadas ou cautelares são o periculum in mora (perigo da demora) e 
o fumus bonis juri (probabilidade do direito). Para Carlo Calvosa (apud THEODORO JÚNIOR, Humberto, 2006, p.478) o periculum in mora é: "Perigo de dano próximo ou iminente é, por sua vez, o que se relaciona com uma lesão que provavelmente deva ocorrer ainda durante o curso do processo principal, isto é, antes da solução definitiva ou de mérito." Pela análise do Código de processo civil de 2015, o periculum in mora se configura no perigo de dano ou risco ao resultado efetivo do processo.

O outro pressuposto para existencia das tutelas urgentes consiste no fumus bonis juris, ou "fumaça do bom direito", onde a parte deverá demonstrar a existencia do direito tutelado. A própria jurisprudencia prenuncia que:

O fumus boni iuris consiste na probabilidade de existência do direito invocado pelo autor da ação cautelar. Direito a ser examinado aprofundadamente em termos de certeza, apenas no processo principal já existente, ou então a ser instaurado. A existência do direito acautelado é, no processo cautelar, aferida em termos de probabilidade e, por isso, seu exame é menos aprofundado, superficial mesmo - sumaria cognitio (do ac. unân. da $15^{\mathrm{a}}$ Câm. do TJSP, de 7.6.89, na apel. 144.007-2, rel. dês. Ruy Camilo; RJTJSP 121/104)

O Novo Código de Processo Civil, em concordância com a ideia trazida na doutrina e na jurisprudência, dispõe de tal maneira:

Art. 305. A petição inicial da ação que visa à prestação de tutela cautelar em caráter antecedente indicará a lide e seu fundamento, a exposição sumária do direito que se objetiva assegurar e o perigo de dano ou o risco ao resultado útil do processo.

Não há espaço para questionamentos relacionados à exigência dos pressupostos típicos das tutelas provisórias urgentes. Ressalte-se que os requisitos enunciados funcionam como prova de valoração dada à tutela provisória. O periculum in mora, e o fumus bonis juris constituem própria e especificamente ao conteúdo meritório da providência provisória. Devese portando, questionar a veracidade apresentada pelos pressupostos presentes em cada caso. Sendo os requisitos preenchidos, ou seja, estando eles presentes e de maneira válida, há possibilidade de aplicação de tutelas provisórias urgentes.

\section{Indeferimento Liminar e Deferimento de Plano do Pedido de Liberdade}

O significado de liminar, na língua portuguesa relaciona-se com um "momento inicial", ou aquilo que antecede o assunto mais importante. A petição de habeas corpus, ao chegar ao 
juiz ou à autoridade do tribunal responsável pelo seu despacho, pode acarretar no indeferimento liminar de instauração do processo, ou seja, por algum motivo, poderá ser negada liminarmente a instauração do processo, por decisão do juiz de primeiro grau, do tribunal, da câmara ou turma. As razões para tal indeferimento são: quando não for competente o órgão judiciário para aquilo, ou for inepta a inicial, ou havendo carência de condição de ação. A incompetência e a falta de condição de ação devem ser evidentes e a inépcia não poderá ser sanada.

No caso de ser deferido o processamento do pedido, o código de processo penal autoriza de plano o acolhimento, independente da apresentação do paciente e recebimento das informações do coator (artigos 656 e 662 CPP parte 1). Raramente o acolhimento do pedido de plano, de forma definitiva (e não apenas cautelar e provisório), acontece, porém, quando ocorre, é amparado pela lei.

Do Código de Processo Penal, extraímos do artigo 649: "O juiz ou o tribunal, dentro dos limites da sua jurisdição, fará passar imediatamente a ordem impetrada, nos casos em que tenha cabimento, seja qual for a autoridade coatora." Portanto, não há de se confundir aqui a aceitação de plano do pedido com a possibilidade de liminar em habeas corpus, esta última, criação jurisprudencial.

Sobre a possibilidade de deferimento de plano do pedido, Frederico Marques (p.426427) leciona que:

O habeas corpus pode ser concedido de plano e liminarmente, sem necessidade
de ser apresentado o paciente, ou de se requisitarem informaçães da autoridade
coatora. Daí a regra expressa do art. 649 do Código de Processo Penal, in verbis:
"O juiz ou o Tribunal, dentro dos limites da sua jurisdição, fará passar
imediatamente a ordem impetrada, nos casos em que tenha cabimento, seja qual
for a autoridade coatora". E o art. $660, \S 2^{\circ}$, do Código de Processo Penal, ainda
de modo mais claro estatui: "Se os documentos que instruírem a petição
evidenciarem a ilegalidade da coação, o juiz ou o tribunal ordenará que cesse
imediatamente o constrangimento".

O artigo 649 traz essencialmente limitações ao poder de atuação do juiz ou do tribunal, e trata também do imediatismo de suas decisões, e o artigo 660 determina um prazo de 24 horas, após as diligências e a oitiva do paciente, para que o juiz decida em função dos seis parágrafos desse artigo. 


\section{A Procedência da Liminar em Habeas Corpus}

Uma característica essencial do procedimento do habeas corpus é o rito sumaríssimo ao qual se submete a fim de garantir prontamente tutela à liberdade de locomoção. O objetivo do habeas corpus é soltar rapidamente a pessoa detida. A preocupação com a celeridade do writ o segue desde o Código de Processo Criminal de 1832, como meio de restituição de liberdade ou evitar ou fazer cessar de pronto a prisão ou constrangimento ilegal. Pelo código de processo penal vigente, o prazo para determinar uma decisão final é de 24 horas (artigo 660), e nos tribunais, o julgamento deve ocorrer na primeira ou segunda sessão após o recebimento das informações, independentemente de publicação da pauta de julgamento (artigo 664).

O habeas corpus, em sua tramitação já é uma ação suficientemente célere, apta a permitir o julgamento do mérito, independente de liminar. Em alguns casos, todavia, a medida se torna indispensável. Marques diz que: “Toda a vez em que o habeas corpus é concedido, seja para evitar prisão injusta, ou para impedir prisão prolongada, embora sem pôr cobro à persecutio criminis, o seu caráter de providência cautelar está presente."

Podemos ilustrar tal caso usando o exemplo de quando, preso preventivamente, as provas dos autos indicam atuação em legítima defesa. Contrário ao artigo 314 do CPP, faz-se mister usar a liminar para liberar o detido ou impedir a prisão do acusado. A primeira liminar em sede de habeas corpus do direito pátrio se deu, no Habeas Corpus 27.200, impetrado no Superior Tribunal Militar por Arnold Wald, favorecendo Evandro Moniz Côrrea de Menezes, concedida pelo Ministro Almirante de Esquadra José Espíndola, em 31 de agosto de 1964, em pleno regime militar. Suas palavras foram: "Como preliminar, determino que o sr. Encarregado do inquérito se abstenha de praticar qualquer ato contra o paciente, até definitivo pronunciamento deste tribunal." Tratava-se de habeas corpus voltado a impedir que o paciente fosse investigado por fato ocorrido em repartição sem qualquer relação com a administração militar.

Concedida pela segunda vez também perante um tribunal militar em 1964, o relator, ao deferir a liminar, fez um paralelo entre a mesma e o mandado de segurança, além de referir-se aos pressupostos das tutelas de urgência, como observou Tourinho Filho (1998 p.721):

\footnotetext{
"Se, no mandado de segurança, pode o Relator conceder a liminar, até em casos em que está em jogo a liberdade individual ou as liberdades públicas,
} 
a liminar, no habeas corpus preventivo, não pudesse ser concedida". Evidente que para a concessão da medida extrema, observou o grande Magistrado - como era e é de rigor - , devem estar patentes os pressupostos das cautelares, isto é, o periculum in mora e o fumus boni juris

E continua, ao fazer analogia com o mandado de segurança:

(...) Se o processo é o mesmo, e se no mandado de segurança pode o relator conceder a liminar até em casos de interesses patrimoniais, não se compreenderia que, em casos em que está em jogo a liberdade individual ou as liberdades públicas, a liminar, no habeas corpus preventivo não pudesse ser concedida, principalmente, quando o fato ocorre em dia de sábado, feriado forense, em que o Tribunal nem no dia seguinte abre suas portas.

Registre-se que há discordância minoritária em relação à analogia feita entre liminar em habeas corpus e o mandado de segurança. Para Pedro Gagliardi, o artigo 660, §2 do CPP, fundamenta juridicamente a aplicação de liminar em habeas corpus, tornando-se a analogia desnecessária para embasar decisão (BUSANA, 2009).

O mandado de segurança foi instituído na constituição de 1934, e nesta mesma carta é posto que seu processo "será o mesmo do habeas corpus." Foram necessárias quase três décadas para que a jurisprudência permitisse ao habeas corpus a liminar permitida ao mandado de segurança. Diante do exposto, percebe-se que em alguns casos, mesmo com a conhecida celeridade da qual reveste-se o habeas corpus, há a necessidade de se utilizar medidas liminares afim de proteger ou resgatar com urgência o direito à liberdade de locomoção.

A concessão de liminar em habeas corpus demanda os dois pressupostos já estudados: o fumus bonis juris, ou juízo de probabilidade ou verossimilhança no tocante a futuro deferimento da ordem, e o periculum in mora, assim como a impossibilidade, no caso em questão, da concessão de plano do habeas corpus.

Recorrendo à jurisprudência, analisamos o habeas corpus $\mathrm{n}^{\circ} 322.807$ - SP (2015/0102451-2), impetrado por Tiago Bellucci, em favor do paciente Samuel de Jesus Queiroz Correa, preso preventivamente pela suposta prática do crime previsto no art. 33, caput, da Lei n. 11.343/2006, em que o impetrante requeria a revogação da preventiva justificando a existência de pressupostos autorizadores da custódia cautelar, requisitando liminarmente a concessão da ordem para determinar a soltura imediata do paciente até a decisão final do writ. O relator, ministro Newton Trisotto ao prolatar decisão deferindo liminar, destaca: 
[...]Vê-se que não foram apontados quaisquer elementos concretos que pudessem justificar a custódia cautelar. Está apoiada apenas na gravidade abstrata do crime de tráfico de drogas.

Nesse contexto, é forçoso concluir que a pretensão do impetrante reveste-se de fumaça do bom direito com densidade suficiente a autorizar a concessão da liminar postulada. (HC 322.807/SP (2015/0102451-2), rel. Newton Trisotto, 13.05.2015, v.u.).

Fica evidente que havendo dúvida no que toca à substancialidade do crime, em caso que evidencie de modo flagrante, coação ilegal ou advinda de abuso de poder, em detrimento do direito de liberdade, cabe tutela de urgência a fim de sanar o litigio. Concedida ou não concedida a liminar, não cabe recurso. Em sequência, o feito vai ser apreciado por turma ou câmara.

Por não caber recurso, há os que impetrem habeas corpus no Tribunal, após negativa do juiz, para obter o que não foi conseguido em primeiro grau. Caso o relator indefira a liminar, impetra-se no Superior Tribunal de Justiça e, em se negando a liminar pelo Ministro relator, vai-se ao Superior Tribunal Federal, gerando nas palavras de Nucci uma "cascata de habeas corpus", que ao final, esgota-se na Súmula 691 do STF, que diz que: "Não compete ao Supremo Tribunal Federal conhecer de habeas corpus impetrado contra decisão do relator que, em habeas corpus requerido a tribunal superior indefere a liminar. ”.

A edição da Súmula busca de certa forma evitar que o referido efeito, de que tantas impetrações do remédio aconteçam. Ao analisarmos os números de habeas corpus concedidos entre 2009 e 2018 no STF, não restam dúvidas de como o número habeas corpus vem diminuindo.

Demonstra-se com o gráfico e a tabela a seguir: 


\begin{tabular}{|c|c|c|c|c|c|}
\hline & $\begin{array}{l}\text { Concedida a } \\
\text { ordem }\end{array}$ & $\begin{array}{l}\text { Concedida a } \\
\text { ordem de ofício }\end{array}$ & $\begin{array}{l}\text { Concedida em } \\
\text { parte a ordem }\end{array}$ & Provido & Soma: \\
\hline 2.018 & 87 & 58 & 19 & & 164 \\
\hline 2.017 & 339 & 159 & 45 & & 543 \\
\hline 2.016 & 213 & 213 & 46 & 1 & 473 \\
\hline 2.015 & 167 & 117 & 47 & & 331 \\
\hline 2.014 & 189 & 171 & 61 & & 421 \\
\hline 2.013 & 194 & 173 & 68 & & 435 \\
\hline 2.012 & 244 & 121 & 108 & & 473 \\
\hline 2.011 & 330 & 55 & 82 & & 467 \\
\hline 2.010 & 302 & 90 & 55 & & 447 \\
\hline 2.009 & 342 & 47 & 39 & & 428 \\
\hline Soma: & 2.407 & 1.204 & 570 & 1 & 4.182 \\
\hline
\end{tabular}

$600-$

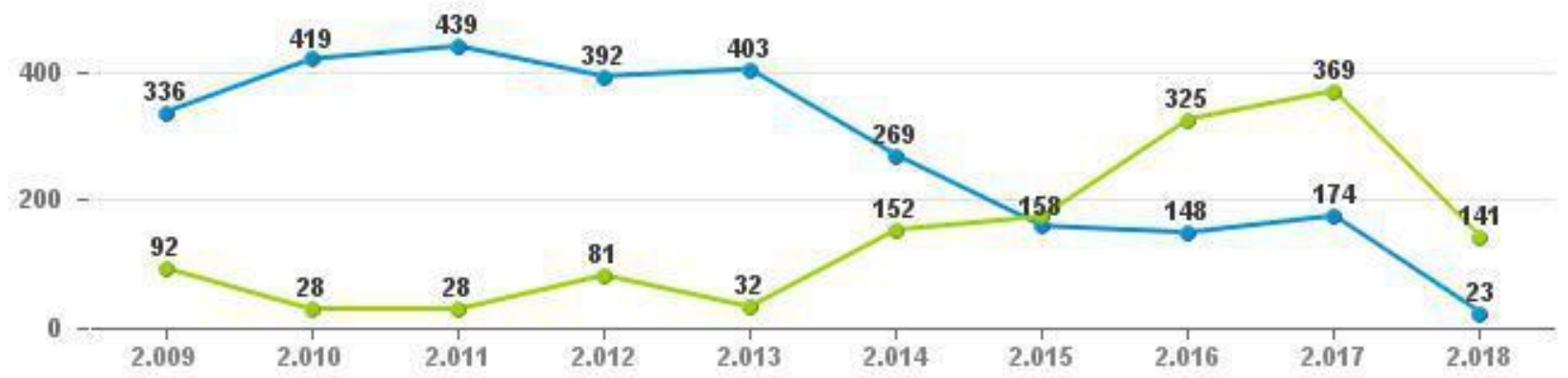

Fonte: STF/2018

Contra o entendimento, Alberto Zacharias Toron argumenta ser inadmissível que haja tal limitação à garantia constitucional que resguardar tão importante direito como o de locomoção. Aury Lopes Júnior, faz crítica à Súmula, pois pondera que aguardar o julgamento do mérito do writ após negativa de liminar poderia levar a uma espera de meses e até anos para que o impetrante possa prosseguir ingressando com um novo mandamus no Tribunal Superior. 
Toron vai além e preleciona que as impetrações sucessivas não maculam a hierarquia dos graus de jurisdição e nem a competência dos tribunais; propondo por fim o cancelamento da súmula.

A possível revogação da súmula não encontrou amparo na Suprema Corte, no entanto, seu abrandamento vem acontecendo através do deferimento de habeas corpus fronte à negativa de liminar em situações de flagrante ilegalidade. Havendo evidente teratologia, não se nega ao paciente apreciação pela Suprema Corte.

Nas palavras de Tourinho Filho "uma das mais belas criações da nossa jurisprudência foi a de liminar em pedido de habeas corpus, assegurando de maneira mais eficaz o direito de liberdade.” (TOURINHO FILHO, Fernando da Costa. Processo Penal, 2013, p. 679).

As controvérsias acerca do uso, concessão ou não de medidas liminares em habeas corpus advém principalmente pela falta de previsão legal e sua consequente dificuldade na interposição de recursos, às particularidades de cada caso que abrem espaço para a discricionariedade e responsabilidade do magistrado em responder questões prévias e sumárias que determinarão a garantia ao direito de liberdade de um cidadão.

\section{Conclusões}

No Brasil, o habeas corpus foi introduzido no ordenamento jurídico pátrio e passou por transformações para que fosse adequado ao momento social vivenciado no passado. Passandose os anos e evoluindo a sociedade, o homem vai aperfeiçoando as ferramentas que tem a sua disposição para melhor adaptar-se ao momento político e social. Em se tratando de habeas corpus, uma dessas ferramentas é a liminar.

A liminar é uma tutela provisória de urgência, podendo ser assecuratória ou satisfatória, ambos os casos admitidos também em sede de habeas corpus, a depender se este é do tipo preventivo ou repressivo, ou seja, se de fato se consumou a ameaça à liberdade de locomoção. Não há um dispositivo legal positivado que fundamente o uso da liminar no habeas corpus, porém, o judiciário ao entender que se fazia necessário uma maior rapidez em garantir o direito de locomoção através do habeas corpus, estabeleceu judicialmente a possibilidade de concederse habeas corpus. A liminar também cria um maior controle dos abusos do poder estatal.

O estudo demonstra que o uso da analogia e dos princípios gerais do direito encontra-se em conformidade com o ordenamento jurídico pátrio, tanto pela Constituição Federal de 1988 
como pela possibilidade legal disposta nos artigos $3^{\circ}$ do Código de Processo Penal e artigo $4^{\circ}$ da Lei de Introdução ao Código Civil. Sendo assim, permite-se e goza de legalidade a analogia de liminar no Mandado de Segurança com a fundamentação dada pelo poder judiciário para conceder a liminar em habeas corpus.

Contra a liminar indeferida em habeas corpus não cabe recurso. Quando não concedida a liminar, deve-se impetrar uma nova ação em instância superior. A Súmula 691 do STF, aprovada em 2003 estabelece limites ao poder judiciário quando se preocupa em evitar a “supressão de instância". Ou seja, dispondo que não é da competência do STF julgar habeas corpus originário sem devida apreciação do mérito por instância inferior. O abrandamento da súmula vem por meio de concessão de liminar em casos teratológicos e excepcionais.

Por fim, chegamos a conclusão com o estudo em tela, que não cabe nem mesmo a mais alta corte judicial do país denegar a justiça. A Súmula tratada continua vigente, porém deve ser flexibilizada, pois se reclama a concessão de liminar em habeas corpus devido à urgência da medida e a demora no julgamento do writ. Quando se busca a tutela da liberdade do cidadão, é inadmissível a morosidade jurisdicional.

\section{Referências}

CAMPOS, Antonio Macedo de. Habeas-corpus: doutrina, legislação, pratica. Imprenta: Bauru, Jalovi, 1982.

BRASIL. Supremo Tribunal Federal. Estatísticas STF. Disponível em:< http://www.stf.jus.br/portal/cms/verTexto.asp?servico=estatistica\&pagina=hc $>$. Acesso em: $10 / 05 / 2018$

CANOTILHO, J.J. Gomes. Direito Constitucional,6ed.Livraria Almedina,1995.

CALVOSA, 1970 apud THEODORO JÚNIOR, Humberto. Curso de direito processual civil: Processo de execução e cumprimento de sentença, processo cautelar e tutela de urgência. 40. ed. - Rio de Janeiro: Forense, 2006, v. 2. p. 478.

DOS REIS, 1948 apud_. Código de Processo Penal e sua interpretação jurisprudencial: doutrina e jurisprudência. 2. ed. rev., atual. e ampl. - São Paulo: Editora Revista dos Tribunais, 2004, v.1. p. 1543.

GRECCO FILHO, V ICENTE. Tutela constitucional das liberdades. São Paulo: Saraiva, 1989. 
GRINOVER, 1984 apud FRANCO, A. S.; STOCO, R. (Coord). Código de Processo Penal e sua interpretação jurisprudencial: doutrina e jurisprudência. 2. ed. rev., atual. e ampl. - São Paulo: Editora Revista dos Tribunais, 2004, v. 1. p. 1543.

MACHADO, Joaquim de Oliveira. O habeas-corpus no Brasil: Recurso popular e protector à liberdade individual. Rio de Janeiro: Casa dos Editores Proprietários Eduardo\&Henrique Laemmert, 1878. p.10

MELLO, Abdon de. Habeas-Corpus, "Repertório de Jurisprudência", $2^{a}$ ed. Ampliada, Livraria do Globo, Porto Alegre: 1941, p. 12.

MIRANDA, Jorge. Manual de Direito Constitucional. 3.ed. Coimbra: Coimbra, 1996. t. II.

MORAES, Alexandre de. Direito constitucional. 15. ed. São Paulo, Atlas: 2015.

PACHECO, José Ernani de Carvalho. Habeas Corpus: prática, processo e jurisprudência. 1976. p.22.

PINHEIRO, Joaquim. Roma nas Vidas Paralelas de Plutarco. Espaços e paisagens: antiguidade clássica e heranças contemporâneas: Vol.1 Línguas e Literaturas: Grécia e Roma. Coimbra, 2012. Disponível em: < http://digitalis.uc.pt/handle/10316.2/31791>

PACHECO, José Ernani de Carvalho. Habeas corpus. 7. ed. Curitiba: Juruá, 1998.

PONTES DE MIRANDA. Tratado de Direito Privado. 4.ed. São Paulo: RT, 1983. t. IV.

História e prática do habeas-corpus: direito constitucional e processual comparado. Imprenta: Rio de Janeiro, Borsoi, 1962.

SILVA, Joabson Carlos Pereira. Habeas corpus per saltum: (im)possibilidade de afastamento "hic et nunc" do óbice estabelecido pelo verbete de Súmula $n^{\circ} 691$ do Supremo Tribunal Federal. Revista Jus Navigandi, ISSN 1518-4862, Teresina, ano 17, n. 3270, 14 jun. 2012. Disponível em: 〈https://jus.com.br/artigos/22006>. Acesso em: 1 jun. 2018.

TORNAGHI, Hélio Bastos. Curso de processo penal. 6 ed. São Paulo: Saraiva, 1989.

TOURINHO FILHO, Fernando da Costa. Código de processo penal comentado. 3. ed. rev. modificada e ampl. - São Paulo: Saraiva, 1998, v. 2.

Como citar este artigo (Formato ABNT):

SANTAGUIDA, Barbara Maria Moreira Dante; MARINHO, Gisanne de Oliveira; SANTIAGO, Juliana de Fátima dos Santos; FARIAS, Athena de Albuquerque. A Medida Liminar em Habeas Corpus. Id on Line Rev.Mult. Psic., 2018, vol.12, n.41, p.725-747. ISSN: 1981-1179.

Recebido: 04/07/2018

Aceito 13/07/2018 